\title{
Rare ECG finding in a patient with severe hypercalcaemia
}

\author{
Grace Chaplin (10 , ${ }^{1,2}$ Ankita Malik, ${ }^{2}$ Ravish Katira ${ }^{2}$
}

${ }^{1}$ School of Medicine, University of Liverpool, Liverpool, UK ${ }^{2}$ Cardiology, St Helens and Knowsley Teaching Hospitals NHS Trust, Prescot, UK

\section{Correspondence to}

Grace Chaplin;

graceachaplin@gmail.com

GC and AM contributed equally.

Accepted 10 May 2021

\section{DESCRIPTION}

A man in his late 60 s with a significant history of decompensated alcohol-related liver disease was admitted to hospital with a 2 -week history of increasing jaundice and pruritus as well as confusion, drowsiness and a decreased exercise tolerance. Routine bloods revealed an exceptionally elevated corrected calcium level which peaked at $5.17 \mathrm{mmol} / \mathrm{L}$. On admission, Alpha-fetoprotein (AFP) was also greatly increased (126278 U/L). These two derangements were later discovered to be due to an underlying diagnosis of hepatocellular carcinoma on CT. Due to his severe hypercalcaemia, the patient was admitted to the coronary care unit

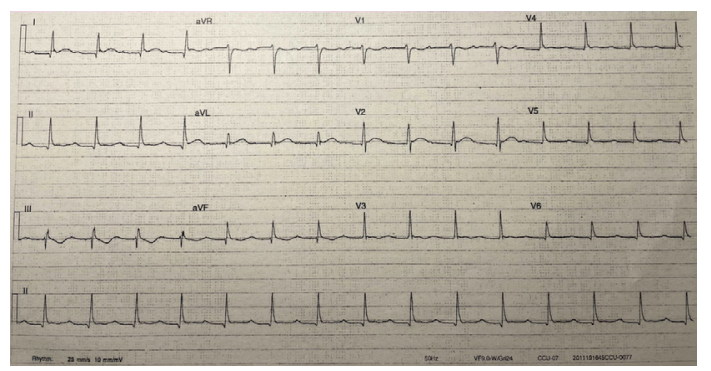

Figure 1 ECG showing sinus rhythm with a heart rate of $82 \mathrm{bpm}$. QTc was $422 \mathrm{~ms}$. There is evidence of first-degree heart block (PR interval $308 \mathrm{~ms}$ ) and T wave inversion.

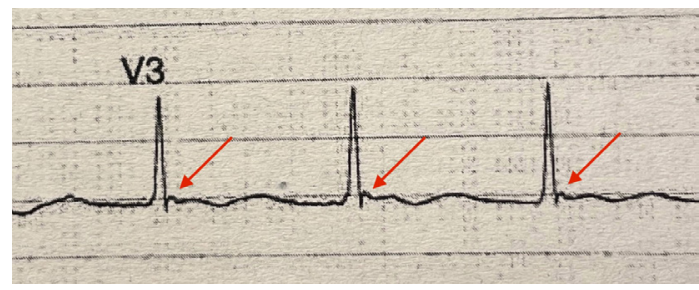

Figure 2 The most notable finding on this tracing is the Osborn wave, seen most clearly in V3 (indicated by red arrows).

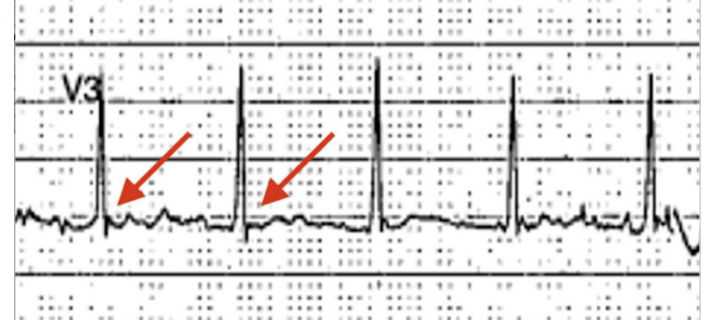

Figure 3 Post-therapy ECG showing resolution of Osborn waves (recorded 3 days after figure 1). for cardiac monitoring and treatment. This patient was treated with immediate fluid resuscitation, intravenous pamidronate and calcitonin in order to reduce his calcium levels. A 12-lead ECG was performed (figure 1) which showed Osborn waves (figure 2). This resolved after therapy (figure 3). Although an MRI liver was arranged for a more detailed assessment, unfortunately he deteriorated significantly and became encephalopathic. Despite optimal treatment, the patient died, receiving supportive input from the palliative care team.

The Osborn ('J') wave is a deflection occurring at the $\mathrm{J}$ point (junctional point between the $\mathrm{R}$ wave and ST segment) on the ECG. The phenomenon was described first in the early 20th century by Kraus et al in patients with hypercalcaemia ${ }^{1}$ but was named decades later after Osborn, who detailed the characteristic deflection induced by experimental hypothermia in animals. ${ }^{2}$ Although most commonly associated with hypothermia, rare causes of the presence of Osborn waves on an ECG include hypercalcaemia, as in this case, and subarachnoid haemorrhage. ${ }^{3}$ This characteristic deflection is posited to be mediated by the increased prominence of the cardiac transient outward potassium current

\section{Learning points}

Osborn waves are an important ECG feature to observe for in patients presenting with hallmark signs of hypercalcaemia; for example, abdominal or bone pain, lethargy, weakness or new confusion (remembered as 'stones, bones, abdominal moans and psychic groans').

- Hypercalcaemia is important to diagnose and treat in the acute setting due to the risk of cognitive impairment and life-threatening arrhythmias (for which patients should be on continuous cardiac monitoring).

- Hypercalcaemia is most commonly caused by primary hyperparathyroidism (for which a Parathyroid Hormone (PTH) level is required) or malignancy, but can also be seen in a variety of other conditions including Addison's disease, drug toxicity (eg, with thiazide diuretics or lithium), thyrotoxicosis and multiple endocrine neoplasia.

- Acute treatment of hypercalcaemia consists first of immediate and extensive fluid therapy, followed by bisphosphonates (eg, pamidronate) or calcitonin (third-line agent) if calcium levels are unresponsive (alongside seeking specialist endocrinology advice). 
$\left(\mathrm{I}_{\text {to }}\right)$ and subsequently increased transmural gradient occurring in the epicardium, although direct evidence is lacking. ${ }^{4}$

Twitter Grace Chaplin @gracechaplin

Contributors Both $\mathrm{GC}$ and $\mathrm{AM}$ contributed equally to the writing of this paper. RK conceived and designed the paper and provided final approval of the published version.

Funding The authors have not declared a specific grant for this research from any funding agency in the public, commercial or not-for-profit sectors.

Competing interests None declared.

Patient consent for publication Next of kin consent obtained.

Provenance and peer review Not commissioned; externally peer reviewed.
ORCID iD

Grace Chaplin http://orcid.org/0000-0001-7901-1850

\section{REFERENCES}

1 Kraus F. Ueber die Wirkung des Kalziums auf den Kreislauf ${ }^{1}$ ). Dtsch Med Wochenschr 1920;46:201-3.

2 Osborn JJ. Experimental hypothermia; respiratory and blood pH changes in relation to cardiac function. Am J Physiol 1953;175:389-98.

3 De Sweit J. Changes simulating hypothermia in the electrocardiogram in subarachnoid hemorrhage. J Electrocardiol 1972;5:193-5.

4 Antzelevitch C. J wave syndromes: molecular and cellular mechanisms. J Electrocardiol 2013;46:510-8.

Copyright 2021 BMJ Publishing Group. All rights reserved. For permission to reuse any of this content visit

https://www.bmj.com/company/products-services/rights-and-licensing/permissions/

BMJ Case Report Fellows may re-use this article for personal use and teaching without any further permission.

Become a Fellow of BMJ Case Reports today and you can:

- Submit as many cases as you like

- Enjoy fast sympathetic peer review and rapid publication of accepted articles

- Access all the published articles

Re-use any of the published material for personal use and teaching without further permission

Customer Service

If you have any further queries about your subscription, please contact our customer services team on +44 (0) 2071111105 or via email at support@bmj.com.

Visit casereports.bmj.com for more articles like this and to become a Fellow 